\title{
Buccal bifurcation cyst as an incidental finding in cone beam computed tomography scans
}

\section{Cisto da bifurcação vestibular como um achado incidental em exames de tomografia computadorizada de feixe cônico}

\author{
Anne Caroline OENNING ${ }^{1}$ iD 0000-0001-9731-8629 \\ Luciana Butini OLIVEIRA $^{1}$ (iD) 0000-0002-8755-6540 \\ José Luiz Cintra JUNQUEIRA ${ }^{1}$ iD 0000-0001-6788-4021 \\ Saulo L. SOUSA MELO² iD 0000-0003-2299-5769
}

\begin{abstract}
Buccal bifurcation cyst is an unusual inflammatory odontogenic cyst of unknown etiology which occurs at the buccal region of the permanent mandibular first molars in children and adolescents aged 6-15 years old. The aim of this manuscript is to present two clinical cases of buccal bifurcation cyst incidentally detected in adolescents referred for tomographic exams (CBCT) as part of the treatment planning for the management of impacted mandibular molars. The first case is very interesting due to the proximity of the lesion to the inferior alveolar canal. In the second case the inferior alveolar canal was not in close proximity to the lesion, but in contact with the mesiobuccal root of the second molar. The diagnosis of Buccal bifurcation cyst is of utmost importance in order to avoid complications during surgical procedures. In addition, the present case reports have highlighted the importance for dental practitioners to be aware of the possibility of a buccal bifurcation cyst being present as an incidental finding in CBCT images, especially in young patients.
\end{abstract}

Indexing terms: Cone beam computed tomography. Diagnosis. Odontogenic cysts. Surgery, Oral.

\section{RESUMO}

O cisto da bifurcação vestibular é uma lesão odontogênica inflamatória, incomum e de etiologia desconhecida que ocorre na região vestibular de primeiros molares permanentes inferiores em crianças e adolescentes na faixa etária de 6-15 anos. O objetivo deste trabalho é apresentar dois casos clínicos de cisto da bifurcação vestibular detectados incidentalmente em imagens de tomografia computadorizada de feixe cônico de adolescentes, indicadas como parte do tratamento e avaliação de terceiros molares inferiores impactados. O primeiro caso relatado é bastante interessante devido à presença de cisto de bifurcação bucal ter proximidade com o canal mandibular. No segundo caso o canal alveolar inferior não estava próximo da lesão, mas em contato com a raiz mésiovestibular do segundo molar. O diagnóstico da bifurcação vestibular é de grande relevância para evitar possíveis complicações durante a realização de cirurgias. Os casos relatados destacam a importância para os cirurgiões-dentistas estarem cientes da possibilidade de um Cisto da bifurcação vestibular estar presente como um achado incidental em imagens de tomografia computadorizada de feixe cônico, especialmente em pacientes jovens.

Termos de indexação: Tomografia computadorizada de feixe cônico. Diagnóstico. Cistos odontogênicos. Cirurgia bucal.

\section{$\checkmark v \nabla v$}

1 Faculdade São Leopoldo Mandic, Instituto de Pesquisas São Leopoldo Mandic, Radiologia. Rua José Rocha Junqueira, 13, Swift, 13045-755, Campinas, SP, Brasil. Correspondência para / Correspondence to: AC OENNING. E-mail: <anne.oenning@slmandic.edu.br>.

${ }^{2}$ The University of lowa, Department of Oral Pathology, Radiology \& Medicine - College of Dentistry. Iowa City, IA, USA.

\footnotetext{
$\mathbf{v} \mathbf{v}$
}

Como citar estar artigo / How to cite this article

Oenning AC, Oliveira LB, Junqueira JLC, Sousa Melo LS. Buccal bifurcation cyst as an incidental finding in cone beam computed tomography scans. RGO, Rev Gaúch Odontol. 2018;66(4):385-389. http://dx.doi.org/10.1590/1981-863720180004000013JL 


\section{INTRODUCTION}

Buccal bifurcation cyst (BBC) is an unusual inflammatory odontogenic cyst that occurs at the buccal region of the permanent mandibular first or second molars in children aged 6-8 years old [1,2]. Some authors reported that it is most common in 6- to 15-year-old patients and it is not found in adults $[3,4]$. BBC does not occur in the maxilla and can be bilateral [3].

The first case of bifid mandibular canal was published by Stoneman and Worth in 1983 as the mandibular infected buccal cyst [5]. The Buccal bifurcation cyst can appears as an incidental finding in cone beam computed tomography scans. There are few case reports of $B B C$ in the literature and their frequency in relation to all odontogenic cysts varies between 0.9 and $4.7 \%$ [6].

The $B B C$ diagnosis is primarily based on specific clinical and radiographic findings and it cannot be dignosed from the histopathologic features [1]. CBCT characteristics include buccal expansion, sometimes interradicular bone loss, periosteal bone reaction and resorption of the vestibular plate [4]. The treatment of choice is enucleation and curettage of the lesion without extraction of the vital involved tooth. According to the liyterature, this procedure has shown excellent results in short- and long-term, as well $[2,7,8]$.

The present article reports two cases of buccal bifurcation cyst incidentally identified in adolescents otherwise referred for tomographic exams as part of the treatment planning for the management of impacted mandibular molars.

\section{CASE REPORTS}

\section{Case 1}

A 13-year-old male was referred to an Oral and Maxillofacial Radiology service for consultation. It was observed the intraoral absence of the mandibular left second molar; the lower right second molar was normally erupted and in normal occlusion with the opposite arch. Clinical examination of the left second molar region showed the normal aspect of the mucosa and no changing in size or shape of the alveolar ridge was observed.

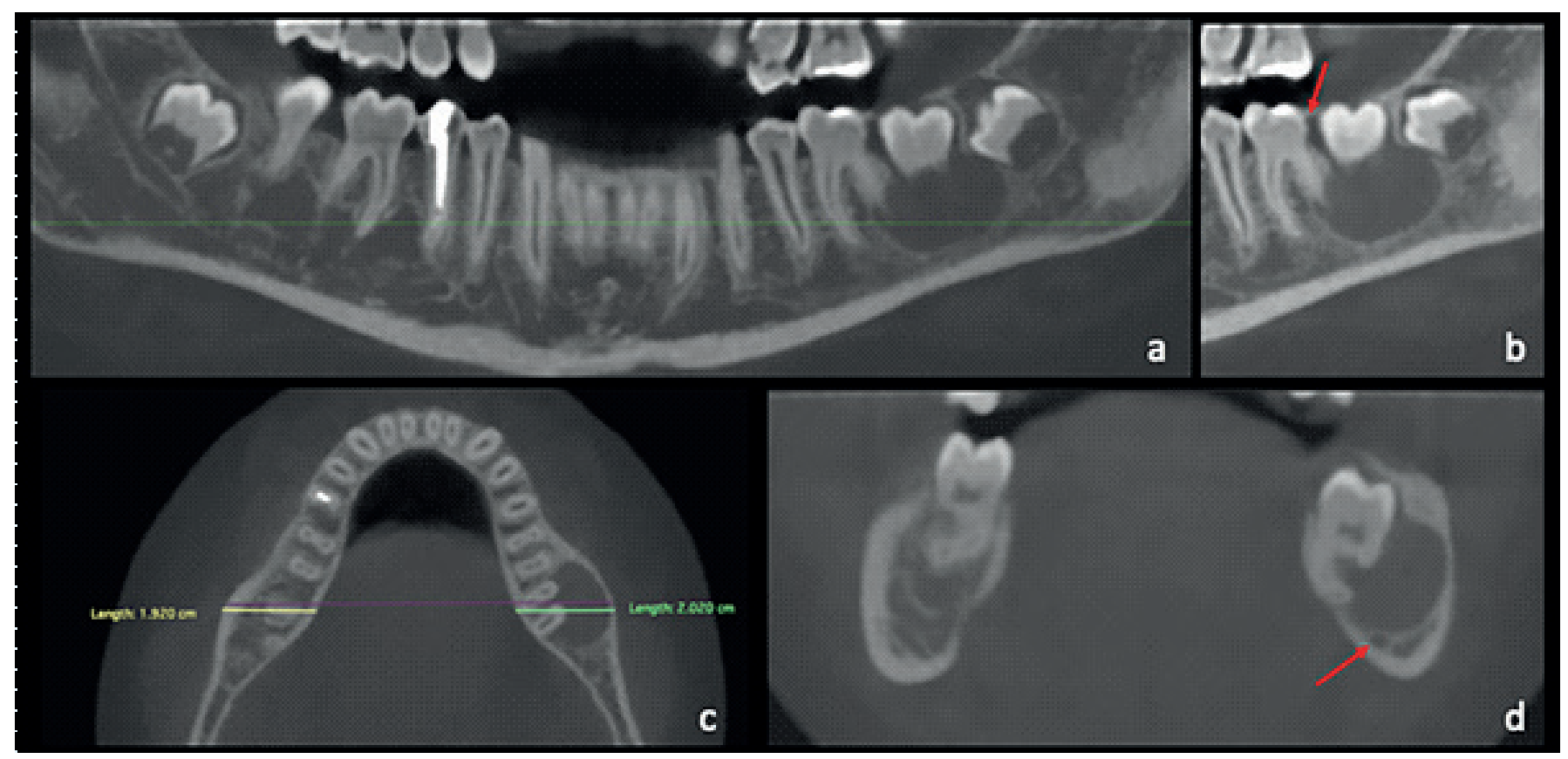

Figure 1. CBCT exam. (a) Panoramic reconstruction (0.3mm thickness) showing the partially erupted left second molar and a hypodense rounded lesion - the buccal bifurcation cyst - with the upper limit in the cervical region of the second molar. (b) The sagittal reconstruction evidenced a possible source for infection (arrow) that probably triggered the lesion. (c) The axial reconstruction shows the absence of a considerable expansion of the mandibular alveolar process (green line: lesion side, $2.02 \mathrm{~cm}$; yellow line: contralateral side, $1.92 \mathrm{~cm}$ ). (d) The close proximity of the lesion to the inferior alveolar canal is evident in the coronal view. 
A cone beam computed tomography (CBCT) scan was performed using an i-CAT Classic CBCT unit (Imaging Sciences International, Hatfield, PA), operating at $120 \mathrm{kVp}$ and $5 \mathrm{~mA}$, with a $0.30-\mathrm{mm}$ voxel size and field of view of $6-\mathrm{cm} \times 16-\mathrm{cm}$. A well-defined, corticated, unilocular, rounded hypodense lesion was observed with approximately $2-\mathrm{cm}$ in its greatest dimension, located at the furcation of the lower left second molar (figure 1). The close proximity of the lesion to the inferior alveolar canal was also noted (figure 1-d). There was no evidence of periosteal reaction or cortical disruption. The tomographic features of the lesion, associated with age of the patient and the pathognomonic location, were consistent with a buccal bifurcation cyst. Surgical intervention was performed by means of enucleation of the lesion, extraction of the adjacent developing third molar, and preservation of the second molar in place. The histopathologic exam confirmed the diagnosis of an inflammatory cystic lesion.

\section{Case 2}

A 17-year-old female was referred to an oral surgeon for extraction of the mandibular third molars for orthodontic reasons.

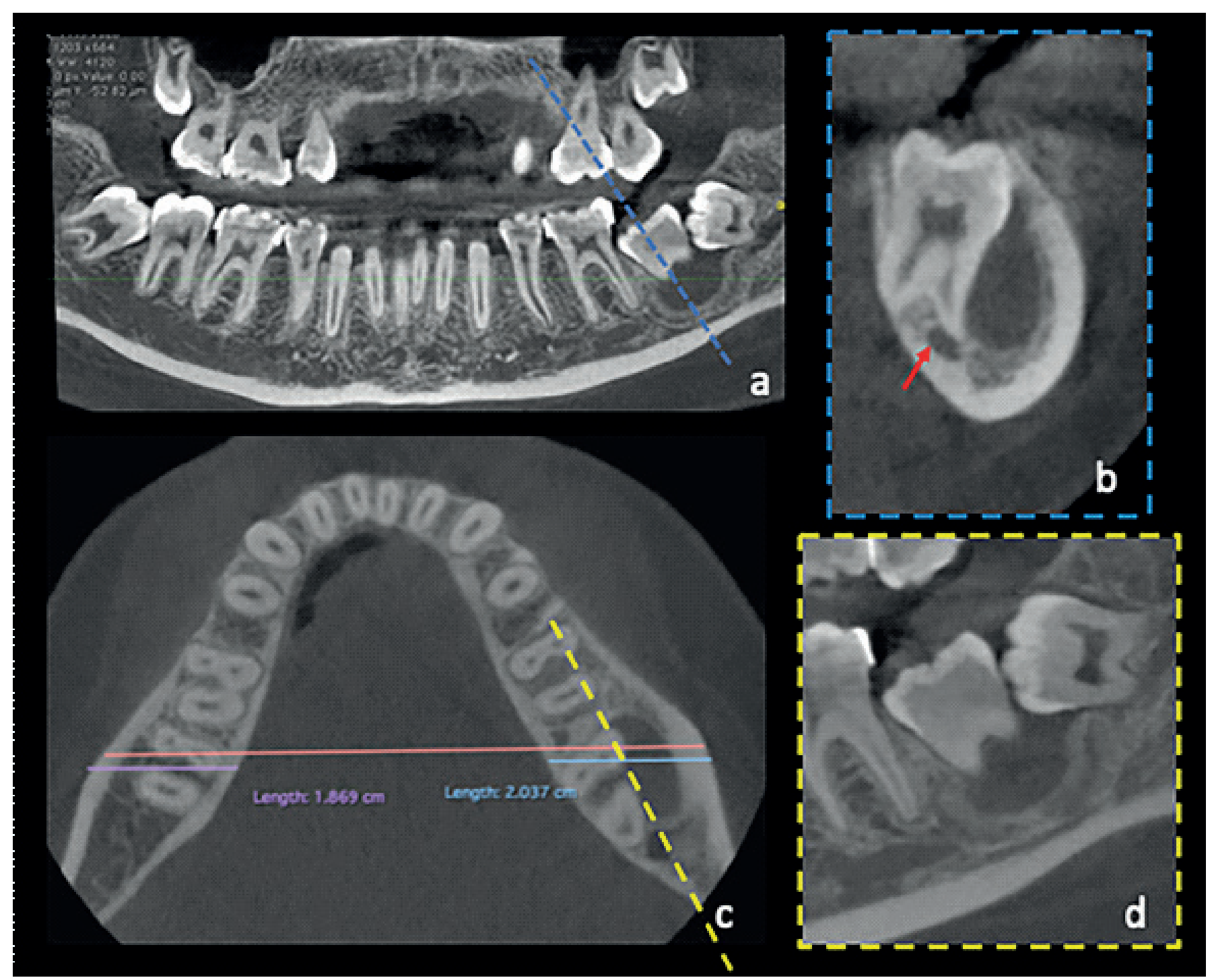

Figure 2. CBCT exam. (a) Panoramic reconstruction $(0.18 \mathrm{~mm}$ thickness) showing a cystic lesion which the upper limit is located in the cervical region of the impacted left second molar. The interrupted blue line demonstrates the region and inclination of the cross-sectional reconstruction (b). (b) There was evident close relationship between the mesiobuccal root of the second molar and the inferior alveolar canal. A bone reaction (sclerosis) surrounding the lesion was also observed. (c) The axial reconstruction highlights the absence of meaningful expansion of the mandible in the region of the lesion (blue line: lesion side, $2.0 \mathrm{~cm}$; purple line: normal side, $1.8 \mathrm{~cm}$ ). The interrupted yellow line indicates the region and orientation of the sagittal reconstruction (d). (d) Close relationship between the impacted second and third molars. 
During the intraoral examination, the clinician also noticed the absence of the mandibular left second molar, while the contralateral second molar was normally erupted. There was no evidence of swelling in the region. A CBCT examination was requested given that, according to the referring doctor, the two-dimensional radiographies had shown a close proximity of both third molars to the inferior alveolar canal.

The CBCT scan was performed in a CS9300 unit (Carestream, Rochester, USA) under the protocol of $90 \mathrm{kVp}$, $4 \mathrm{~mA}, 0.18-\mathrm{mm}$ voxel size and field of view of $8 \times 8-\mathrm{cm}$. A well-defined, corticated, unilocular, rounded hypodense lesion located facial to the furcation of the mandibular left second molar was observed (figure 2). The second and third molars were both impacted. No significant expansion of the mandibular alveolar process was noted (figure 2-c). However, the facial cortex of the mandible appeared slightly thicker in the region of the lesion (figure 2-c). Differently from case 1, the inferior alveolar canal was not in close proximity to the lesion, but in contact with the mesiobuccal root of the second molar.

Considering the tomographic features, pathognomonic location and the high likelihood of an inflammatory stimulation through the area of impaction (figure 2-d), the diagnosis of buccal bifurcation cyst was considered. The surgical procedure involved enucleation of the lesion combined with the extraction of the third molar and preservation of the second molar. The biopsy confirmed the preliminary diagnosis of buccal bifurcation cyst.

\section{FINAL CONSIDERATIONS}

The BBC is frequently asymptomatic and can remain undetected on clinical and radiographic examination. However, it is sometimes diagnosed incidentally on CBCT images [7]. In the present paper both cases involved an impacted tooth, however the condition can be associated to normally erupted teeth if there is a periodontal pocket or other infection/ inflammation pathway. Nonetheless, tooth impaction is very often a source of infection.

According to the imaging and clinical findings, the differential diagnosis of this lesion included lateral radicular cyst, lateral periodontal cyst, dentigerous cyst, eruption cyst, and others [1]. It is worth mentioning the role of CBCT scans in the diagnosis and management of this condition given that those lesions are usually poorly visualized, and sometimes not detected at all, in two-dimensional exams. In the first case report the CBCT images were essential in order to identify the proximity of the lesion to the inferior alveolar canal. In the second case the inferior alveolar canal was not in close proximity to the lesion, but in contact with the mesiobuccal root of the second molar.

In most cases the treatment of choice is enucleation and curettage of the lesion without extraction of the involved tooth. CBCT scans may help reducing the risk of tooth injury during surgical interventions as it provides a better visualization of the area.

\section{CONCLUSION}

The present article has highlighted the importance of dental practitioners' awareness of a buccal bifurcation cyst being present as an incidental finding, especially in young patients and in teeth prone to periodontal infection and/or inflammation.

\section{Collaborators}

OENNING AC and LB OLIVEIRA were in charge of writing the draft of the paper. JLC JUNQUEIRA critically revised the paper. SOUSA MELO SL performed the computed tomography evaluation and critically revised the paper. All authors have approved the final version to be published.

\section{REFERENCES}

1. Derindağ G, Miloğu Ö, Sümbülü MA. Buccal bifurcation cyst (paradental cyst) defined by ultrasonography and conebeam computed tomography. Oral Radiol. 2018 Jul 26. doi: 10.1007/s11282-018-0339-7. [Epub ahead of print]

2. Kim HR, Nam SH, Kim HJ, Choi SY. Buccal bifurcation cyst: two case reports and a literature review. J Clin Pediatr Dent. 2018;42(3): 221-4. https://doi.org/10.17796/1053-4628-42. 3.10

3. Friedrich RE, Scheuer HA, Zustin J. Inflammatory paradental cyst of the first molar (buccal bifurcation cyst) in a 6-yearold boy: case report with respect to immunohistochemical findings. In Vivo. 2014; 28(3):333-9.

4. De Grauwe A, Mangione F, Mitsea A, Kalyvas D, Yfanti Z, Ahbab G, et al. Update on rare mandibular osteolytic lesion in childhood: the buccal bifurcation cyst. BJR Case Rep. 2018;4(2):20170109. https://doi.org/10.1259/bjrcr.20170109 
5. Stoneman DW, Worth HM. The mandibular infected buccal cyst--molar area. Dent Radiogr Photogr.1983;56:1-14.

6. Philipsen HP, Reichart PA, Ogawa I, Suei Y, Takata T. The inflammatory paradental cyst: a critical review of 342 cases from a literature survey, including 17 new cases from the author's files. J Oral Pathol Med. 2004;33(3):147-55. https:// doi.org/10.1111/j.0904-2512.2004.00139.x

7. Borgonovo AE, Rigaldo F, Censi R, Conti G, Re D. Large buccal bifurcation cyst in a child: a case report and literature review. Eur J Paediatr Dent. 2014; 15(2 Suppl):237-40.
8. Levarek RE, Wiltz MJ, Kelsch RD, Kraut RA. Surgical management of the buccal bifurcation cyst: bone grafting as a treatment adjunct to enucleation and curettage. J Oral Maxillofac Surg. 2014;72(10):1966-73. doi: 10.1016/j.joms.2014. 04.028

Received on: 9/3/2018 Final version resubmitted on: 22/8/2018

Approved on: 15/9/2018 